\title{
Myalgia Frequency in Patients with COVID-19 and Its Relationship with Creatine Kinase Levels
}

\author{
COVID-19 Hastalarında Myalji Sıklığı ve Kreatin Kinaz Düzeyleri ile İlişskisi
}

\author{
Nimet UÇAROĞLU CAN \\ (D) 0000-0003-1307-3578 \\ Özgecan KAYA \\ (D) 0000-0003-4328-8932 \\ Dilcan KOTAN \\ (D) 0000-0002-8624-6321
}

Sakarya University Faculty of Medicine Department of Neurology, Sakarya, Turkey

\section{Corresponding Author Sorumlu Yazar \\ Nimet UÇAROĞLU CAN nimetucaroglu37@hotmail.com}

Received / Gelis Tarihi : 04.08.2020 Accepted / Kabul Tarihi : 24.10.2020 Available Online /

Çevrimiçi Yayın Tarihi : 25.11.2020

\begin{abstract}
Aim: Many studies have showed that myalgia is a common onset symptom in coronavirus disease 2019 (COVID-19). This study aimed to determine the frequency of muscle pain in patients followed with COVID-19 diagnosis, and to investigate the relationship between muscle pain and creatine kinase (CK), $\mathrm{pH}$, lactate and lactate dehydrogenase (LDH) levels. Material and Methods: One hundred ten patients diagnosed with COVID-19 in our hospital were included retrospectively in this study. Presence of myalgia at the time of admission and on the 14th day of control were investigated. The first admission laboratory findings, 3rd day CK values and 14th day control CK values of all patients were recorded retrospectively from their files.

Results: The study included 110 patients diagnosed with COVID-19. Fifty patients (45.5\%) had muscle pain at the time of admission, and it was one of the most common musculoskeletal complaints. High CK results were obtained in $48(43.6 \%)$ of the 110 patients at the time of admission. Thirty-two $(66.7 \%)$ of 48 patients with high CK had muscle pain $(\mathrm{p}<0.001)$. In the patients with muscle pain, the CK levels observed on $1^{\text {st }}, 3^{\text {rd }}$, and $14^{\text {th }}$ day of the disease were found to be significantly higher than in those without muscle pain $(p<0.001, p=0.003$, $\mathrm{p}=0.029$ ). No significant relationship was found between complaints of muscle pain and lactate, $\mathrm{pH}$, and $\mathrm{LDH}$ values.

Conclusion: Since some patients may only present with musculoskeletal symptoms such as myalgia, it is important that clinicians consider COVID-19 in patients presenting with myalgia and high CK levels.

Keywords: COVID-19; myalgia; creatine kinase.
\end{abstract}

ÖZ

Amaç: Birçok çalışma miyaljinin koronavirüs hastalığ 2019 (coronavirus disease 2019, COVID-19)'da sık görülen bir başlangıç semptomu olduğunu göstermiştir. Bu çalışmada COVID-19 tanısıyla takip edilen hastalarda kas ağrısı sıklığının belirlenmesi ve kas ağrısı ile kreatin kinaz (creatine kinase, CK), pH, laktat ve laktat dehidrogenaz (LDH) düzeyleri arasındaki ilişkisinin araştırılması amaçlandı.

Gereç ve Yöntemler: Bu çalışmaya hastanemizde COVID-19 tanısı almış olan 110 hasta geriye dönük olarak dahil edildi. Başvuru sırasında ve 14. gün kontrolde miyalji yakınması olup olmadığı incelendi. Tüm hastaların ilk başvurudaki laboratuvar bulguları, 3. gün CK değerleri ve 14. gün kontrolündeki CK değerleri dosyalarından geriye dönük olarak kaydedildi. Bulgular: COVID-19 tanısı almış 110 hasta çalışmaya alındı. Elli hastada $(\% 45,5)$ başvuru anında kas ağrısı vardı ve en sık görülen kas iskelet sistemi şikâyetlerinden biriydi. Yüz on hastanın 48 'inde $(\% 43,6)$ bașvuru anında CK yüksekliği saptandı. CK yüksekliği saptanan 48 hastanın 32 'sinde $(\% 66,7)$ kas ağrısı vardı $(p<0,001)$. Kas ağrısı olan hastalarda $1 ., 3$. ve 14 . günde bakılan CK düzeyleri kas ağrısı şikayeti olmayanlara göre anlamlı derecede yüksek bulundu ( $<<0,001 ; p=0,003 ; p=0,029)$. Kas ağrısı yakınması ile laktat, $p H$ ve LDH değerleri arasında anlamlı ilişki bulunmadı.

Sonuç: Başvuru sırasında yalnızca miyalji gibi kas iskelet sistem semptomları bulunan hastalar olabileceğinden, miyalji ile başvuran ve CK yüksekliği saptanan hastalarda COVID-19'un akılda tutulması önem arz etmektedir.

Anahtar kelimeler: COVID-19; miyalji; kreatin kinaz. 


\section{INTRODUCTION}

Coronavirus disease 2019 (COVID-19) is a disease caused by a new type of coronavirus, severe acute respiratory syndrome coronavirus 2 (SARS-CoV-2). This coronavirus has genetic similarities with severe acute respiratory syndrome coronavirus 1 (SARS-CoV-1), which was responsible for the epidemic of severe acute respiratory syndrome (SARS) in 2013. SARS-CoV-2 first emerged in China in December 2019 and soon spread to the rest of the world. The most common symptoms in adults are fever, cough, fatigue, dyspnea, anorexia, diarrhea, and myalgia $(1,2)$. Many studies have shown that myalgia is a common (36\%) onset symptom in COVID-19 (3).

Similar to other types of coronavirus causing acute respiratory failure, the spike (S) proteins of SARS-CoV-2 bind to the angiotensin-converting enzyme 2 (ACE2) receptors, and proteolytic cleavage occurs via the serine protease transmembrane protease serine 2 (4-6). ACE2 receptors have been shown in the brain, kidney, vascular smooth muscle, and skeletal muscles $(7,8)$. SARS-CoV-2 can spread through the bloodstream or vascular endothelium, causing infection in all ACE2 receptorcontaining tissues, including the musculoskeletal system. SARS-CoV-2 can affect skeletal muscle cells by binding with ACE2 alone or with the proinflammatory cytokines interleukin-6 (IL-6), interleukin-10 (IL-10) and tumor necrosis factor-alpha (TNF- $\alpha)$. Increased creatine kinase (CK) and lactate dehydrogenase (LDH) levels during COVID-19 infection are indicative of muscle involvement. As a result of cell damage, lactate levels increase (7), and the oxygen-carrying capacity of erythrocytes and the transport of oxygen to tissues are significantly reduced due to hyperlactatemia. The muscles, therefore, remain ischemic during the COVID-19 infection period (9). The expression of growth factors and inflammatory cytokines increases in the ischemic muscle tissue, and these endogenous substances cause excessive stimulation of the dorsal root ganglions. This stimulation is interpreted as pain by projection into the thalamus and cortex via ascending pathways (10). Myalgia is thought to reflect the systemic inflammation and cytokine response found in patients with COVID-19 (11). In addition, TNF$\alpha$ is responsible for the intense fragmentation of muscle proteins by direct action (12). This can cause focal muscle fiber necrosis and diffuse muscle fiber atrophy, as previously demonstrated in studies of SARS-CoV-1 infection $(13,14)$. Muscle pain that does not respond to classic analgesics decreases with a reduced viral load, decreased inflammation, and lower muscle lactate levels. This study aimed to determine the frequency of muscle pain in patients followed with a diagnosis of COVID-19 and to investigate the relationship between muscle pain and $\mathrm{CK}, \mathrm{pH}$, lactate, and $\mathrm{LDH}$ levels.

\section{MATERIAL AND METHODS}

In this retrospective single-center study, the medical records of patients diagnosed with COVID-19 between April and May 2020 in our hospital were screened retrospectively. In total, 110 patients with confirmed diagnosis of COVID-19 by reverse-transcription polymerase chain reaction (RT-PCR) assays from throat and nasal swab samples used for SARS-CoV-2 virus analysis and chest computed tomography findings were included in the study. The demographic, clinical, and laboratory findings of the patients were recorded in their files. The patients were asked about the presence of myalgia at the time of admission and on the $14^{\text {th }}$ day of control. The $\mathrm{CK}, \mathrm{LDH}$, lactate, and $\mathrm{pH}$ laboratory findings of all the patients were recorded on the $3^{\text {rd }}$ day and again on the $14^{\text {th }}$ day of control and reviewed retrospectively. CK values over $171 \mathrm{U} / \mathrm{L}$ are considered high in our laboratory. The relationship between myalgia and the laboratory parameters was examined. The study was carried out in accordance with the principles of the Declaration of Helsinki with the approval of the Ministry of Health following approval by the local ethics committee. The study was approved by the Ethics Committee of Sakarya University Faculty of Medicine (10.07.2020, 416).

\section{Statistical Analysis}

Kolmogorov-Smirnov test was used to evaluate whether the distribution of numerical variables was normal. Accordingly, Mann-Whitney U test was used to compare the numerical variables, and Chi-square test was used to compare the categorical variables between the groups. The numerical variables were presented as median, interquartile range, minimum-maximum, and categorical variables were presented as a count and percentage. A pvalue $<0.05$ was considered statistically significant. Analyses were performed using IBM SPSS Statistics v. 22.

\section{RESULTS}

The study included 110 patients (63 male, 47 female) who had been diagnosed with COVID-19. The mean age of the patients was $47.13 \pm 15.06$ (range, 18-73) years. The demographic characteristics of the patients are shown in Table 1. Fifty (45.5\%) patients had muscle pain at the time of admission, and it was one of the most common musculoskeletal complaints. On the $14^{\text {th }}$ day, $12(10.9 \%)$ patients had ongoing muscle pain. In our study, $5(4.5 \%)$ patients had only myalgia at the time of admission. High CK results were obtained in $48(43.6 \%)$ of the 110 patients at the time of admission. Thirty-two $(66.7 \%)$ of these patients had muscle pain $(\mathrm{p}<0.001)$.

Table 1. Demographic and clinical features of the patients

\begin{tabular}{lc}
\hline Patients diagnosed with COVID-19 & n (\%) \\
\hline Gender & $63(57.3)$ \\
$\quad$ Male & $47(42.7)$ \\
Female & $48(43.6)$ \\
CK level at admission & $62(56.4)$ \\
$\quad$ High & \\
$\quad$ Normal & $31(28.2)$ \\
CK level on $3^{\text {rd }}$ day & $79(71.8)$ \\
$\quad$ High & \\
$\quad$ Normal & $13(11.8)$ \\
CK level on $14^{\text {th }}$ day & $97(88.2)$ \\
$\quad$ High & \\
$\quad$ Normal & $50(45.5)$ \\
Myalgia at admission & $60(54.5)$ \\
$\quad$ Yes & \\
$\quad$ No & $12(10.9)$ \\
Myalgia on the $14^{\text {th }}$ day & $98(89.1)$ \\
$\quad$ Yes & \\
$\quad$ No &
\end{tabular}


A significant difference was not observed on admission and on the $14^{\text {th }}$ day of control according to the gender $(p=0.360$ and $p=0.188$, Table 2). On days 1 and 3 , the $C K$ values for the male patients were significantly higher than those of the female patients (both $\mathrm{p}<0.001$ ). On day 14 , there was no significant difference in $\mathrm{CK}$ values between the female and male patients.

The median CK values observed on days 1,3 , and 14 of control were $248.5,150.5$ and $80.0 \mathrm{U} / \mathrm{L}$ in the patients with muscle pain, respectively, while the median CK values of those without muscle pain were 96.0, 74.5 and $68.0 \mathrm{U} / \mathrm{L}$ respectively. In the patients with muscle pain, the $\mathrm{CK}$ levels observed on days 1,3 , and 14 of the disease were found to be significantly higher than in those without muscle pain $(\mathrm{p}<0.001, \mathrm{p}=0.003, \mathrm{p}=0.029)$. No significant relationship was found between complaints of muscle pain and lactate, $\mathrm{pH}$, and $\mathrm{LDH}$ values (Table 3 ).

In the patients with muscle pain, high $\mathrm{CK}$ results were observed on $1^{\text {st }}, 3^{\text {rd }}$, and $14^{\text {th }}$ day of the disease to be significantly higher than in those without muscle pain $(\mathrm{p}<0.001, \mathrm{p}=0.001, \mathrm{p}=0.003$, Table 4).

\section{DISCUSSION}

The biochemical parameters used in the diagnosis of COVID-19 play a major role in predicting the course and prognosis of the disease and directing its treatment. Since the emergence of the pandemic, researchers have concentrated their work on determining easily applicable practical parameters. Myalgia is known to be common in the early stages of COVID-19. We therefore evaluated CK levels, which we predicted could be a favorable parameter for evaluating myalgia.

Myalgia can occur as a symptom of many diseases, and viral infections are one of the main causes. In the course of a viral infection, IL-6 most frequently mediates myalgia (15). Since the SARS-CoV-2 agent causes a strong inflammatory response, high cytokine levels (IL-6, IL-10, and TNF- $\alpha$ ) are detected, especially in patients with a moderate or severe disease course $(16,17)$. Although the exact mechanism of myalgia during viral infection is not known, it is thought that proinflammatory cytokines cause muscle pain directly (i.e., TNF- $\alpha$ on muscle proteins) and indirectly (i.e., PGE2 stimulates nociceptive pathways causing a pain sensation). Myalgia caused by COVID-19 lasts longer and is more severe than myalgia caused by other viral infections. In patients with COVID-19, myalgia and fatigue do not respond to classic analgesics.

There is a relationship between high CK levels and muscle damage. CK levels begin to rise approximately 2-12 hours after the onset of muscle damage and start to decrease to their basal values in 3-5 days (18).

In our study, 110 patients diagnosed with COVID-19 were evaluated retrospectively. Among these, 50 (45.5\%) patients had myalgia on admission, and 48 (43.6\%) patients had CK elevation on admission. The control CK values on days 1,3 , and 14 were higher among the patients presenting with myalgia than those without myalgia. Although we found a significant relationship between myalgia and high CK levels, there was no significant relationship between myalgia and lactate, $\mathrm{pH}$, and $\mathrm{LDH}$ values.

Several studies (19-22) have reported that patients with a diagnosis of COVID-19 and high serum levels of ferritin,
Table 2. Myalgia and creatine kinase levels according to the gender of the patients

\begin{tabular}{lccc}
\hline & $\begin{array}{c}\text { Male } \\
(\mathbf{n = 6 3})\end{array}$ & $\begin{array}{c}\text { Female } \\
(\mathbf{n = 4 7 )}\end{array}$ & $\mathbf{p}$ \\
\hline Myalgia at admission & $31(49.2)$ & $19(40.4)$ & 0.360 \\
Myalgia on the $14^{\text {th }}$ day & $9(14.3)$ & $3(6.4)$ & 0.188 \\
High CK level at admission & $39(61.9)$ & $9(19.1)$ & $<\mathbf{0 . 0 0 1}$ \\
High CK level on the $3^{\text {rd }}$ day & $27(42.9)$ & $4(8.5)$ & $<\mathbf{0 . 0 0 1}$ \\
High CK level on the $14^{\text {th }}$ day & $12(19.0)$ & $1(2.1)$ & $\mathbf{0 . 0 0 7}$ \\
\hline CK: creatine kinase & & &
\end{tabular}

Table 3. Comparison of laboratory values of patients with and without myalgia at admission

\begin{tabular}{lccc}
\hline & $\begin{array}{c}\text { M (+) } \\
(\mathbf{n = 5 0})\end{array}$ & $\begin{array}{c}\mathbf{M}(-) \\
(\mathbf{n = 6 0})\end{array}$ & $\mathbf{p}$ \\
\hline CK at admission & $248.5(459)$ & $96.0(115)$ & $<\mathbf{0 . 0 0 1}$ \\
& {$[39-2103]$} & {$[24-353]$} & \\
CK on the $3^{\text {rd }}$ day & $150.5(301)$ & $74.5(83)$ & $\mathbf{0 . 0 0 3}$ \\
& {$[28-1266]$} & {$[22-359]$} & \\
CK on the $14^{\text {th }}$ day & $80(73)$ & $68(54)$ & $\mathbf{0 . 0 2 9}$ \\
& {$[27-315]$} & {$[20-198]$} & \\
Lactate & $1.6(1.2)$ & $1.7(1.0)$ & 0.794 \\
& {$[0.8-4.3]$} & {$[0.2-3.4]$} & \\
pH & $7.39(0.06)$ & $7.38(0.05)$ & 0.693 \\
& {$[7.27-7.47]$} & {$[7.30-7.55]$} & \\
LDH & $235(95)$ & $234(100)$ & 0.147 \\
& {$[151-574]$} & {$[97-596]$} & \\
\hline
\end{tabular}

M (+): patients with myalgia at admission, $\mathrm{M}(-)$ : patients without myalgia at admission, CK: creatine kinase, LDH: lactate dehydrogenase, descriptive statistics were given as median (interquartile range) [minimum-maximum]

Table 4. Comparison of creatine kinase levels of patients with and without myalgia at admission

\begin{tabular}{lccc}
\hline & $\begin{array}{c}\text { M (+) } \\
(\mathbf{n = 5 0})\end{array}$ & $\begin{array}{c}\text { M (-) } \\
(\mathbf{n = 6 0 )}\end{array}$ & $\mathbf{p}$ \\
\hline High CK level at admission & $32(64.0)$ & $16(26.7)$ & $<\mathbf{0 . 0 0 1}$ \\
High CK level on the $3^{\text {rd }}$ day & $22(44.0)$ & $9(15.0)$ & $\mathbf{0 . 0 0 1}$ \\
High CK level on the 14 ${ }^{\text {th }}$ day & $11(22.0)$ & $2(3.3)$ & $\mathbf{0 . 0 0 3}$ \\
\hline
\end{tabular}

M (+): patients with myalgia at admission, $\mathrm{M}(-)$ : patients without myalgia at admission, CK: creatine kinase

leukocytes, total bilirubin, and IL-6 (CK) have higher mortality rates. Patients with rhabdomyolysis present with myalgia and high CK levels without typical COVID-19 symptoms; however, patients with COVID-19 diagnosed with very high CK levels due to the direct muscle damage caused by the virus have reportedly developed rhabdomyolysis following viral myositis (17). In our study, although very high CK levels were detected in only two patients, a rapid decrease was observed in the follow up, and kidney functions remained within normal limits. Patients with myalgia and high CK should be followed up more closely for the development of rhabdomyolysis.

It is clear that the SARS-CoV-2 virus affects the musculoskeletal system. In 25 of 33 related studies, weakness, myalgia, and increased CK levels, indicating 
muscle damage, have been reported as symptoms of COVID-19 $(23,24)$. Similarly, in our study, the incidence of high CK levels accompanying muscle pain was statistically significant.

In several studies from China, CK elevation has been reported in patients with COVID-19 who did not develop rhabdomyolysis. In a study of 91 adults, the CK levels of 14 patients were higher than $190 \mathrm{U} / \mathrm{L}$, and 15 had myalgia (2). However, there was no relationship with myalgia in the patients with CK elevation. In another study involving 161 adults diagnosed with COVID-19, 17 patients had CK levels higher than $190 \mathrm{U} / \mathrm{L}$, and 18 had myalgia (1). However, no relationship was found between the CK levels and myalgia. In contrast to these studies, myalgia and high CK levels were correlated in our series.

In another study on the relationship between myalgia and CK levels in patients diagnosed with COVID-19, 140 of 239 patients had high $\mathrm{CK}$ results, and 32 patients with $\mathrm{CK}$ elevation had myalgia (25). In the patients with myalgia, the mean $\mathrm{CK}$ values were $241.05 \pm 137.02 \mathrm{U} / \mathrm{L}$ ( $\min 45.00$ $\mathrm{U} / \mathrm{L}$, max $721 \mathrm{U} / \mathrm{L}$ ), while the mean CK levels in the patients without myalgia were $139.67 \pm 83.80 \mathrm{U} / \mathrm{L}$ (min 21 $\mathrm{U} / \mathrm{L}$, max $451 \mathrm{U} / \mathrm{L}$ ). Similarly to our study, the study found a significant relationship between myalgia and increased CK levels.

A limitation of our study was the lack of analgesic responses among the patients with myalgia because of an inadequate filing system. Furthermore, this was a crosssectional study based on retrospective data. We recommend that it be supported by future multicenter studies with larger patient groups.

\section{CONCLUSIONS}

The typical clinical features associated with COVID-19 include fever, cough, and respiratory distress from the first day, but fatigue and myalgia are also common symptoms. Since some patients may only present with musculoskeletal symptoms such as myalgia, it is important that clinicians consider and evaluate COVID-19 in patients presenting with myalgia and high CK levels.

Ethics Committee Approval: The study was approved by the Ethics Committee of Sakarya University Faculty of Medicine (10.07.2020, 416).

Conflict of Interest: None declared by the authors.

Financial Disclosure: None declared by the authors.

Acknowledgements: None declared by the authors.

\section{REFERENCES}

1. Zheng F, Tang W, Li H, Huang YX, Xie Y, Zhou ZG. Clinical characteristics of 161 cases of corona virus disease 2019 (COVID-19) in Changsha. Eur Rev Med Pharmacol Sci. 2020;24(6):3404-10.

2. Zhao XY, Xu XX, Yin HS, Hu QM, Xiong T, Tang YY, et al. Clinical characteristics of patients with 2019 coronavirus disease in a non-Wuhan area of Hubei Province, China: a retrospective study. BMC Infect Dis. 2020;20(1):311.

3. Lippi G, Wong J, Henry BM. Myalgia may not be associated with severity of coronavirus disease 2019
(COVID-19). World J Emerg Med. 2020;11(3):193-4.

4. Hamming I, Timens W, Bulthuis MLC, Lely AT, Navis GJ, van Goor H. Tissue distribution of ACE2 protein, the functional receptor for SARS coronavirus. A first step in understanding SARS pathogenesis. J Pathol. 2004;203(2):631-7.

5. Hoffmann M, Kleine-Weber H, Schroeder S, Krüger N, Herrler T, Erichsen S, et al. SARS-CoV-2 cell entry depends on ACE2 and TMPRSS2 and is blocked by a clinically proven protease inhibitor. Cell. 2020;181(2):271-80.

6. Li W, Moore MJ, Vasilieva N, Sui J, Wong SK, Berne MA, et al. Angiotensin-converting enzyme 2 is a functional receptor for the SARS coronavirus. Nature. 2003;426(6965):450-4.

7. Cure E, Cumhur Cure M. Comment on "should COVID-19 concern nephrologists? Why and to what extent? The emerging impasse of angiotensin blockade". Nephron. 2020;144(5):251-2.

8. Echeverría-Rodríguez O, Gallardo-Ortíz IA, Del Valle-Mondragón L, Villalobos-Molina R. Angiotensin-(1-7) participates in enhanced skeletal muscle insulin sensitivity after a bout of exercise. $\mathbf{J}$ Endocr Soc. 2020;4(2):bvaa007.

9. Kucuk A, Cumhur Cure M, Cure E. Can COVID-19 cause myalgia with a completely different mechanism? A hypothesis. Clin Rheumatol. 2020;39(7):2103-4.

10. Queme LF, Ross JL, Jankowski MP. Peripheral mechanisms of ischemic myalgia. Front Cell Neurosci. 2017; 11:419.

11. Jiang X, Coffee M, Bari A, Wang J, Jiang X, Huang J, et al. Towards an artificial intelligence framework for data-driven prediction of coronavirus clinical severity. Comput Mater Contin. 2020;63(1):537-51.

12. Drożdżal S, Rosik J, Lechowicz K, Machaj F, Szostak B, Majewski P, et al. COVID-19: Pain management in patients with SARS-CoV-2 infection-molecular mechanisms, challenges, and perspectives. Brain Sci. 2020;10(7):465.

13. Ding Y, Wang H, Shen H, Li Z, Geng J, Han H, et al. The clinical pathology of severe acute respiratory syndrome (SARS): a report from China. J Pathol. 2003;200(3):282-9.

14. Hsiao $\mathrm{CH}$, Chang $\mathrm{MF}$, Hsueh PR, Su IJ. Immunohistochemical study of severe acute respiratory syndrome-associated coronavirus in tissue sections of patients. J Formos Med Assoc. 2005;104(3):150-6.

15. Manjavachi MN, Motta EM, Marotta DM, Leite DFP, Calixto JB. Mechanisms involved in IL-6-induced muscular mechanical hyperalgesia in mice. Pain. 2010;151(2):345-55.

16. Chen G, Wu D, Guo W, Cao Y, Huang D, Wang H, et al. Clinical and immunological features of severe and moderate coronavirus disease 2019. J Clin Invest. 2020;130(5):2620-9.

17. Pedersen SF, Ho YC. SARS-CoV-2: a storm is raging. J Clin Invest. 2020;130(5):2202-5.

18. Borku Uysal BB, Ikitimur H, Yavuzer S, Islamoglu MS, Cengiz M. Case report: a COVID-19 patient presenting with mild rhabdomyolysis. Am J Trop Med Hyg. 2020;103(2):847-50.

19. Ponti G, Maccaferri M, Ruini C, Tomasi A, Ozben T. Biomarkers associated with COVID-19 disease 
progression. Crit Rev Clin Lab Sci. 2020;57(6):389-99.

20. Ruan Q, Yang K, Wang W, Jiang L, Song J. Clinical predictors of mortality due to COVID-19 based on an analysis of data of 150 patients from Wuhan, China. Intensive Care Med. 2020;46(5):846-8.

21. Yang X, Yu Y, Xu J, Shu H, Xia J, Liu H, et al. Clinical course and outcomes of critically ill patients with SARS-CoV-2 pneumonia in Wuhan, China: a singlecentered, retrospective, observational study. Lancet Respir Med. 2020;8(5):475-81.

22. Zhou F, Yu T, Du R, Fan G, Liu Y, Liu Z, et al. Clinical course and risk factors for mortality of adult inpatients with COVID-19 in Wuhan, China: a retrospective cohort study. Lancet. 2020;395(10229):1054-62.

23. Huang C, Wang Y, Li X, Ren L, Zhao J, Hu Y, et al. Clinical features of patients infected with 2019 novel coronavirus in Wuhan, China. Lancet. 2020;395(10223):497-506.

24. Mao L, Jin H, Wang M, Hu Y, Chen S, He Q, et al. Neurological manifestations of hospitalized patients with coronavirus disease 2019 in Wuhan, China. 2020;77(6):683-90.

25. Karadaş Ö, Öztürk B, Sonkaya AR. A prospective clinical study of detailed neurological manifestations in patients with COVID-19. Neurol Sci. 2020;41(8):1991-5. 